\title{
PENGEMBANGAN TANAMAN BAWANG MERAH DI DESA BULUPOUNTU JAYA KECAMATAN SIGI BIROMARU DI TINJAU DARI FAKTOR FAKTOR PRODUKSI
}

\section{DEVELOPMENT OF RED ONION PLANT IN BULUPOUNTU JAYA SIGI BIROMARU DISTRICT AT THE REVIEW OF PRODUCTION FACTORS}

\author{
Hasmari Noer $^{1^{*}}$, Jumardin ${ }^{1}$, Indarti Widya Anggraeni ${ }^{1}$ \\ ${ }^{1}$ Program Studi Agroteknologi, Fakultas Pertanian, Universitas Alkhairaat, Jl. Diponegoro No. 39 \\ Palu Sulawesi Tengah, 94221, Indonesia
}

\begin{abstract}
ABSTRAK
Penelitian ini bertujuan untuk mempelajari dan mengetahui faktor-faktor yang mempengaruhi produksi tanaman bawang merah telah dilaksanakan di Desa Bulupountu Jaya Kecamatan Sigi Biromaru Kabupaten Sigi Provinsi Sulawesi Tengah. Hasil penelitian ini diharapkan dapat menjadi bahan informasi bagi petani tentang faktor-faktor yang mempengaruhi produksi tanaman bawang merah. Penelitian ini dilaksanakan mulai bulan Juni hingga Agustus 2016 di Desa Bulupountu Jaya Kecamatan Sigi Biromaru Kabupaten Sigi Propinsi Sulawesi Tengah. Pemilihan lokasi penelitian ini berdasarkan bahwa DesaBulupountu Jaya mayoritas petani bawang merah. Metode yang digunakan adalah metode penelitian kuantitatif dengan melakukan survey dan wawancara kepada petani yang melakukanu sahatani tanaman bawang merah di Desa Bulupountu Jaya. Penentuan lokasi dilakukan dengan cara purposive sampling yaitu memilih lokasi dengan cara sengaja sedangkan penentuan responden dilakukan dengan Multistage Random Sampling melalui tahapan sebagai berikut : a. Menentukan dusun mewakili wilayah Desa Bulupountu Jaya, b. Menentukan kelompok tani pada setiap dusun c. Menentukan lima responden pada setiap kelompok tani, sehingga terdapat 20 responden. Hasil Penelitian ini menunjukkan bahwa faktor-faktor luaslahan, jumlah pupuk, jumlah benih, penggunaan pestisida dan pengendalian hama mempengaruhi produksi dalam pengembangan usaha tani bawang merah di Desa Bulupountu Jaya Kecamatan Sigi Biromaru Kabupaten SigiProvinsi Sulawesi Tengah.
\end{abstract}

Kata kunci :Pengembangan, bawang merah, factor produksi

\begin{abstract}
This research aims to study and know the factors the production of red onion plant, has been implemented in Bulupountu Jaya, Sigi Biromaru, Sigi, Central Sulawesi. The results of this research is expected to be an information for the farmer about the factors that affect the production of red onion plant. The research was conducted from June to August 2016 in Bulupountu Jaya, Sigi Biromaru, Sigi, Central Sulawesi. Selection of the location of this research is based on that Bulupountu Jaya Village is the majority of red onion farmer. The method used is quantitative research method by survey and interviews to farmers red onion farming in Bulupountu.Location determination by purposive sampling and respondents by Multistage Random Sampling, through the stages : a.Specify the hamlet representing Bulupountu area, Specify farmer groups in each hamlet, c. Specify five respondents in each farmer groups, so there are 20 respondents. The results of this research indicate that the factors of land area, the amount of fertilizer, the number of seeds, the use of pesticides and pest control affect production in the development of onion farming in Bulupountu Jaya Village, Sigi Biromaru Subdistrict Sigi Regency Central Sulawesi Province..
\end{abstract}

Keywords:development; red onion; production factors 


\section{Pendahuluan}

Bawang merah merupakan salah satu komoditas sayuran unggulan yang mempunyai arti penting bagi masyarakat baik dilihat dari nilai ekonomi yang tinggi maupun dari kandungan gizi. Hampir setiap masakan menggunakan bawang merah sebagai pelengkap bumbu penyedap.

Komoditas ini juga merupakan sumber pendapatan dan kesempatan kerja yang memberikan kontribusi cukup tinggi terhadap perkembangan ekonomi suatu wilayah, meskipun minat petani dalam membudidayakan bawang merah cukup kuat namun dalam proses pengusahaannya masih ditemui berbagai kendala, baik kendala yang bersifat teknis maupun ekonomis (Wibowo, 2008).

Pada tahun 2014 produksi bawang merah di Sulawesi Tengah mencapai produksi 28,48 $\mathrm{kw} / \mathrm{ha}$, produktifitas $52,44 \mathrm{kw} / \mathrm{ha}$ dengan luas areal panen 543 ha (BPS, 2015). Rendahnya produksi bawang merah disebabkan oleh masih kurangnya daya serap petani terhadap paket teknologi baru seperti penggunaan bibit berkualitas, penggunaan pupuk yang kurang tepat serta pengendalian hama dan penyakit yang kurang diperhatikan (Sutapradja, 1996).

Peningkatan produksi bawang merah, langkah yang dapat dilakukan untuk mengantisipasi penggunaan pupuk yang tinggi adalah mengoptimalkan kesuburan biologi tanah yang akan meningkatkan ketersediaan hara sehingga mengurangi penggunaan pupuk kimia didukung oleh pendapat Foth (1998), di dalam tanah mikroorganisme memainkan peranan penting sebagai perombak bahan organik, terutama bersel satu dan mikroskopik.

Peningkatan produksi tanaman dapat dilakukan dengan selalu memperhatikan sarana produksi yang merupakan faktor pendukung dalam usaha budidaya. Adapun yang menjadi sarana faktor produksi yakni luas lahan, pupuk, tenaga kerja, benih dan pestisida (Makruf $d k k$., 2012).

Penelitian ini bertujuan untuk mempelajari dan mengetahui faktor-faktor yang mempengaruhi produksi tanaman bawang merah di Desa Bulupountu Jaya Kecamatan Sigi Biromaru Kabupaten Sigi. Hasil penelitian ini

\footnotetext{
${ }^{*}$ Penulis Korespondensi.

E-mail: hasmarinoer7@gmail.com

Telp: +62-81221344908
}

diharapkan dapat menjadi bahan informasi bagi petani untuk faktor-faktor yang mempengaruhi produksi tanaman bawang merah di Desa Bulupountu Jaya Kecamatan Sigi Biromaru Kabupaten Sigi.

\section{Metode Penelitian}

Bahan atau objek penelitian adalah petani yang melakukan usaha tani tanaman bawang merah di Desa Bulupountu Jaya Kecamatan Sigi Biromaru Kabupaten SigiPropinsi Sulawesi Tengah sedangkan alat yang digunakan berupa alat tulis menulis, kuisioner

Metode yang digunakan adalah metode penelitian kuantitatif dengan melakukan survey dan wawancara kepada petani yang melakukan usahatani tanaman bawang merah di Desa Bulupountu Jaya Kecamatan Sigi Biromaru Kabupaten Sigi Propinsi Sulawesi Tengah. Penentuan lokasi dilakukan dengan cara purpossive sampling yaitu memilih lokasi dengan cara sengaja sedangkan penentuan responden dilakukan dengan Multistage Random Sampling melalui tahapan sebagai berikut :a. Menentukan dusun mewakili wilayah Desa Bulupountu, b. Menentukan kelompok tani pada setiap dusun c. Menentukan lima responden pada setiap kelompok tani, sehingga terdapat 20 responden.

\section{Hasil dan Pembahasan}

\section{Karakteristik Responden}

\section{Umur}

Hasil penelitian umur responden petani bawang merah dapat dilihat padaTabel 1 .

Tabel 1. Umur respon den petani bawang merah di Desa Bulupountu Jaya Kecamatan Sigi Biromaru Kabupaten Sigi

\begin{tabular}{cccc}
\hline No. & Umur & Jumlah & Persentase \\
\hline 1. & $20-40$ & 10 & $50 \%$ \\
$2 . \quad>40$ & 10 & $50 \%$ \\
\hline Jumlah & 20 & $100 \%$ \\
\hline \multicolumn{2}{c}{ Berdasarkan } & hasil wawancara dengan
\end{tabular}
responden petani bawang merah di Desa Bulupountu Jaya bahwa umur petani sangat beragam. Berdasarkan wawancara terkait dengan umur responden untuk petani bawang merah di Desa Bulupountu Jaya rata-rata berumur 20-40 tahun sebanyak 10 orang atau $50,00 \%$ dan umur antara $>40$ tahun sebanyak 10 orang atau 50,00 $\%$. Keadaan ini menunjukkan bahwa secara fisik masih sangat mendukung petani bawang merah dalam meningkatkan produksinya. 


\section{Jurnal Agrotech 8 (1) 29-33}

Umur merupakan salah satu faktor yang dapat mempengaruhi kemampuan untuk bekerja dan cara berpikir seseorang dengan umur produktif, maka mereka dapat meningkatkan produksinya dalam usahataninya.

\section{Jenis kelamin}

Hasil penelitian jenis kelamin responden petani bawang merah dapat dilihat pada Tabel 2 .

Tabel 2. Jenis kelamin responden petani bawang merah di Desa Bulupountu Jaya Kecamatan Sigi Biromaru Kabupaten Sigi

\begin{tabular}{clcl}
\hline No. & Jenis kelamin & Jumlah & Persentase \\
\hline 1. & Laki-laki & 20 & $100 \%$ \\
2. & Perempuan & - & - \\
\hline Jumlah & 20 & $100 \%$ \\
\hline
\end{tabular}

Berdasarkan hasil wawancara dengan responden petani bawang merah di Desa Bulupountu bahwa jenis kelamin petani seragam dan hal ini sangat memungkinkan dapat melakukan usahataninya dengan baik.

\section{Tingkat pendidikan}

Hasil penelitian tingkatpendidikan responden petani bawang merah dapat dilihat pada Tabel 3 .

Tabel 3. Tingkat pendidikan responden petani bawang merah di Desa Bulupountu Jaya Kecamatan Sigi Biromaru Kabupaten Sigi

\begin{tabular}{cccc}
\hline No. & Pendidkan & Jumlah & Persentase \\
\hline 1. & SD & 16 & $80 \%$ \\
2. & SLTP & 1 & $5 \%$ \\
3. & SLTA & 2 & $10 \%$ \\
4. & D3 & 1 & $5 \%$ \\
\hline Jumlah & 20 & $100 \%$ \\
\hline
\end{tabular}

Berdasarkan hasil wawancara dengan responden petani bawang merah di Desa Bulupountu bahwa tingkat pendidikan petani sangat beragam. Hasil wawancara menunjukkkan bahwa responden petani bawang merah di Desa Bulupountu yang tertinggitamat Sekolah Dasar (SD) sebanyak 16 orang atau $80,00 \%$, yang terendahtamat Sekolah Menengah Pertama (SMP) sebanyak 1 orang atau 5,00\% dan tamat D3 sebanyak 1 orang. Responden petani bawang merah di Desa Bulupountu menunjukkan bahwa tingkat pendidikannya relatif masih rendah. Namun meskipun demikian para petani sangat berpengalaman dikarenakan petani sudah lama dalam usaha budidaya tanaman bawang merah.

Pendidikan yang bersifat formal dan non formal turut mempengaruhi pemahaman petani dalam mempelajari sesuatu yang ingin dikerjakan
e-ISSN : 2621-7236

p-ISSN : 1858-134X

dalam usaha budidaya tanaman. Tingkat pendidikan erat kaitannya dengan cara berpikir petani dalam memahahi atau mempelajari paket teknologi yang disampaikan melalui bentuk penyuluhan (Rinaldi $d k k ., 2012$ )

Jumlah anggota keluarga

Hasil penelitian anggota keluarga responden petani bawang merah dapat dilihat pada Tabel 4

Tabel 4. Jumlah anggota keluarga responden petani bawang merah di Desa Bulupountu Jaya Kecamatan Sigi Biromaru Kabupaten Sigi

\begin{tabular}{cccc}
\hline No. & $\begin{array}{c}\text { Jumlah anggota } \\
\text { keluarga }\end{array}$ & Jumlah & Persentasi \\
\hline 1. & $1-3$ & 16 & $80 \%$ \\
2. & $4-6$ & 4 & $20 \%$ \\
3. & $>6$ & - & - \\
\hline \multicolumn{2}{l}{ Jumlah } & 20 & $100 \%$ \\
\hline
\end{tabular}

responden petani bawang merah di Desa Bulupountu bahwa jumlah anggota keluarga sangat beragam. Hasil wawancara dan survei petani Bawang merah di Desa Bulupountu bahwa jumlah anggota keluargatertinggi 1-3 sebanyak 16 orang atau $80 \%$, jumlah keluarga 4-6 sebanyak 4 orang atau 20,00\%. Dengan melihat jumlah anggota keluarga petani bawang merah di Desa Bulupountu terkait dengan usahataninya bahwa, dimasa mendatang akan membantu menyelesaikan pekerjaan bagi yang sudah dewasa atau dapat dilakukan secara bergotong royong.

Tenaga kerja merupakan faktor produksi yang perlu diperhitungkan dalam proses produksi dalam jumlah yang cukup, bukan saja dilihat dari tersedianya tenaga kerja saja tetapi kualitas dan macam tenaga kerja perlu juga diperhatikan. Jumlah tenaga kerja ini masih banyak dipengaruhi dan dikaitkan dengan kualitas tenaga kerja, jenis kelamin, musim dan upah tenaga kerja. Bila kualitas tenaga kerja, ini tidak diperhatikan, maka akan terjadi kemacetan dalam proses produksi (Soekartawi, 1990). Menurut Indiarto (2006), faktor input tenaga kerja dengan nilai elastisitas sebesar 0,49 dapat diartikan bahwa untuk setiap tambahan penggunaan tenaga kerja sebesar $1 \%$ akan menaikkan produksi sebesar $0,49 \%$.

\section{Faktor-Faktor yang Mempengaruhi Produksi}

Luas Lahan

Berdasarkan hasil wawancara dengan petani menunjukkan bahwa luas lahan (ha) 


\section{Jurnal agrotech 8 (1) 29-33}

Bawang merah di Desa Bulupountu memiliki luasan yang beragam. Hasil wawancara menunjukkan bahwa, petani bawang merah yang ada di Desa Bulupountu paling banyak memiliki luas lahan 1 ha. Hal ini menunjukkan bahwa peningkatan produksi masih dapat dilakukan karena luas lahan sangat berkaitan dengan jumlah populasi. Menurut Sunarti (2013) bahwa peningkatan luas tanam berkorelasi terhadap peningkatan jumlah tanaman dalam suatu areal sehingga dapat meningkatkan produksi per satuan luasan areal tanam. Lebih jauh dijelsakan oleh Suripto (2005), lahan merupakan salah satu dari faktor produksi dimana faktor produksi itu sendiri adalah semua unsur masukan produksi dapat mendukung terjadinya proses produksi sampai menghasilkan keluaran produksi dalam pengelolaan sumberdaya hutan. Dalam hal ini lahan merupakan faktor utama dalam kegiatan produksi. Luas lahan akan menentukan seberapa besar jumlah populasi yang ada dalam satu areal

\section{Penggunaan Benih}

Berdasarkan hasil observasi dan wawancara dengan responden petani Bawang merah di Desa Bulupountu bahwa penggunaan benih hanya satu varietas yakni varietas lokal lembah palu. Jumlah bawang yang digunakan sangat beragam $(\mathrm{kg} / \mathrm{ha})$ hal terkait dengan luas lahan yang dimiliki petani. Berdasarkan informasi yang diperoleh melalui responden bahwa varieta lokal lembah palu sudah sangat lama digunakan dalam usaha budidaya tanaman bawang merah di Desa Bulupountu. Hal ini diduga bahwa viabilitas serta daya adaptasi lingkungan varietas ini sesuai dengan kondisi setempat.

\section{Jumlah Pupuk}

Berdasarkan hasil wawancara dengan responden menunjukkan bahwa tingkat penggunaan pupuk oleh responden petani bawang merah yang ada di Desa Bulupountu antara 150 hingga $350 \mathrm{~kg} / \mathrm{ha}$.

Hasil wawancara menunjukkan bahwa ada beberapa petani yang menggunakan pupuk yang tinggi itu seiring dengan peningkatan produksi pada tanaman yang diusahakan. Menurut Lais (2012) bahwa dengan penambahan jumlah jumlah jenis pupuk yang tepat dapat memberikan peningkatan ketersediaan unsur yang dibutuhkan tanaman dalam satu kali musim tanam. Dengan penggunaan pupuk yang tidak sesuai dosis tersebut maka produtivitas per satuan lahan dapat menjadi berkurang, sehingga produksi dapat mengalami penurunan. Oleh karena itu, semua
e-ISSN : 2621-7236

p-ISSN : 1858-134X

faktor-faktor produksi yang digunakan, harus dimaksimalkan karena produsen selalu berusaha untuk mencapai keuntungan yang maksimum.

\section{Penggunaan pestisida dan pengendalian}

Pestisida kimia digunakan sebagai alternatif terakhir pengendalian OPT ulat bawang $S$. exigua. Pestisida yang digunakan petani bawang merah di Desa Bulupountu Jaya Kecamatan Sigi Biromaru Kabupaten Sigi untuk mengendalikan OPT pada tanaman bawang merah Ulat bawang (S. exigua) antara lain adalah Endure, Demolis, Dithane, Antracolm, Siklon, Marshal, Prevaton, Counter, Samit.

Tanaman bawang merah merupakan salah satu inang utama Spodoptera exigua. Ulat bawang dikenal sebagai hama yang polifag dan banyak jenisnya. Hama ini disebut sebagai ulat grayak karena serangannya mendadak atau secara tiba-tiba dan menyerang dalam jumlah yang banyak. Menurut Rukmana dan Sugandi (1997) dalam Rusli, dkk., (2010) menyatakan bahwa hama Spodoptera exigua menyerang pertanaman bawang merah sejak fase vegetatif sampai saat panen dan pada saat serangan berat dapat menyebabkan kerugian hingga 100\% apabila tidak dilakukan pengendalian.

Prinsip pengendalian hama tanaman yang di kembangkan oleh manusia dewasa ini adalah menekan jumlah populasi hama yang menyerang tanaman sampai pada tingkat populasi yang tidak merugikan. Komponen pengendalian hama yang dapat di terapkan untuk mencapai sasaran tersebut antara lain pengendalian hayati, pengendalian secara fisik dan mekanik, pengendalian secara kultur teknis dan pengendalian secara kimiawi (Nurhayati, 2011).

\section{Kesimpulan}

Hasil Penelitian ini menunjukkan bahwa faktor-faktor luas lahan, jumlah pupuk, jumlah benih, penggunaan pestisida dan pengendalian hama mempengaruhi produksi dalam pengembangan usahatani bawang merah di Desa Bulupountu Jaya Kecamatan Sigi Biromaru Kabupaten Sigi Provinsi Sulawesi Tengah.

\section{Daftar Pustaka}

BPS, 2015. Data Statistik Provinsi Sulawesi Tengah

Foth, H.D., 1998. Fundamentals of Soil Science. (Dasar-dasar Ilmu Tanah alih bahasa 


\section{Jurnal Grotech 8 (1) 29-33}

Endang Dwi Purbayanti, Dwi Retno Lukita, dan Rahayuning Trimulatsih). Gadjah Mada University Press, Yogyakarta.

Makruf E., Yulie Oktavia dan Eka W. P., 2012. Faktor-faktor yang Mempengaruhi Produksi Padi Sawah di Kabupaten Seluma. Balai Pengkajian Teknologi Pertanian (BPTP) Bengkulu.

Nurhayati, H., 2011. Analisis Hama Ulat Bawang (Spodoptera exigua) Pada Tanaman Bawang Merah (Allium cepa). Paper Klimatologi Terapan. Departemen Geofisika Dan Meteorologi Fakultas Matematika Dan Ilmu Pengetahuan Alam Institut Pertanian Bogor.

Indiarto A. D., 2006. Analisis Faktor-Faktor Produksi Padi di ASEAN menggunakan Cobb-Douglas. UNLAM Tesis.

Lais T. 2012. Penggunaan berbagai Jenis Pupuk Bokashi terhadap Pertumbuhan Tanaman Bawang Merah. Agro. 13 No.1:14-18.

Rahayu dan Berlian, 1994. Bawang Merah. Penebar Swadaya. Jakarta.
e-ISSN : 2621-7236

p-ISSN : 1858-134X

Rusli, R., Arneti, Silvia P.S. 2010. Pengujian Ekstrak Metanol Bunga Kipat (Tithonia diversifolia A. Gray) (Asteraceae) Untuk Mengendalikan Spodoptera exigua Hubner (Lepidoptera: Noctuidae). Manggaro, April 2010 Vol.11 No.1:2532.

Soekartawi, 1990, Teori Ekonomi Produksi, dengan Pokok Bhasan Analisis Fungsi Cobb-Douglas. Rajawali Press, Jakarta.

Sunarti, 2013. Pemanfaatan dan Degradasi Lahan. Jurnal Geografi.Vol 4 : hal 1632.

Suripto, 2005. Pengelolaan Sumberdaya Hutan Bersama Masyarakat. Perum Perhutani Jakarta

Sutapradja, H., 1996. Kaitan Antara Pemberian $\mathrm{Cu}$ dan Dosis $\mathrm{K}, \mathrm{Mg}$ serta Ca Terhadap Pertumbuhan dan Hasil Bawang Merah. Jurnal Hort. Pengembangan Pertanian, Jakarta.

Wibowo, 2008 Budidaya Bawang Putih, Bawang Merah dan Bawang Bombay. Penebar Swadaya. Bandung. 